Kebijakan: Jurnal Ilmu Administrasi

Volume 11, Nomor 1, Januari 2020

E-ISSN: 2656-2820

P-ISSN 1829-5762

\title{
IMPLIKASI, URUSAN DAN PROSPEK OTONOMI DAERAH
}

\author{
Iwan Henri Kusnadi \\ Fakultas Ilmu Administrasi Universitas Subang \\ Kota Subang, Jawa Barat \\ iwanhenri01@gmail.com
}

\begin{abstract}
ABSTRAK
Kebijakan Otonomi Daerah yang pada hakekatnya adalah upaya pemberdayaan dan pendemokrasian kehidupan masyarakat diharapkan dapat memenuhi aspirasi berbagai pihak dalam konteks penyelenggaraan pemerintahan negara serta hubungan Pusat dan Daerah. Berdasarkan UU Nomor 23 tahun 2014 klasifikasi urusan pemerintahan terdiri dari 3 urusan yakni urusan pemerintahan absolut, urusan pemerintahan konkuren, dan urusan pemerintahan umum. Dalam memperhatikan prinsip -prinsip pemberian dan penyelenggaraan Otonomi Daerah dapat diperkirakan prospek ke depan menggunakan berbagai pendekatan. Salah satu pendekatan yang kita gunakan disini adalah aspek ideologi, politik, sosial budaya, dan pertahanan keamanan. diterima dalam penyelenggaraan kehidupan berbangsa dan bernegara. Untuk dapat mewujudkan prospek Otonomi Daerah di masa mendatang tersebut diperlukan suatu kondisi yang kondusif diantaranya yaitu: Adanya komitmen politik dari seluruh komponen bangsa terutama pemerintah dan lembaga perwakilan untuk mendukung dan memperjuangkan implementasi kebijakan Otonomi Daerah; Adanya konsistensi kebijakan penyelenggara negara terhadap implementasi kebijakan Otonomi Daerah; dan Kepercayaan dan dukungan masyarakat serta pelaku ekonomi dalam pemerintah dalam mewujudkan cita-cita Otonomi Daerah.
\end{abstract}

Kata Kunci: Ekonomi, Pemberdayaan, dan Otonomi Daerah.
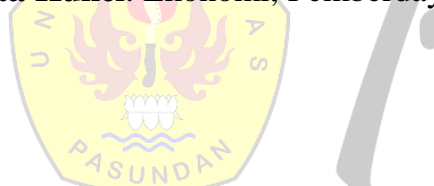

\section{ABSTRACT}

The Regional Autonomy Policy, which is essentially an effort to empower and democratize people's lives, is expected to fulfill the aspirations of various parties in the context of state governance and the relationship between the Central and Regional Governments. Based on Law Number 23 of 2014, the classification of government affairs consists of 3 functions, namely absolute government affairs, concurrent government affairs, and general government affairs. In considering the principles of granting and implementing Regional Autonomy, future prospects can be estimated using various approaches. One of the approaches we use here is ideological, political, socio-cultural, and defense and security aspects. accepted in the implementation of the life of the nation and state. To be able to realize the prospect of Regional Autonomy in the future, conducive conditions are needed, namely: There is political commitment from all components of the nation, especially the government and representative institutions to support and fight for the implementation of Regional Autonomy policies; There is consistency in the policies of state administrators towards the implementation of Regional Autonomy policies; and Public trust and support as well as economic actors in the government in realizing the ideals of Regional Autonomy.

Keywords: Economy, Empowerment, and Regional Autonomy.

\section{PENDAHULUAN}

Pemahaman istilah "otonom" secara bahasa adalah "berdiri sendiri" atau "dengan pemerintahan sendiri". Sedangkan "daerah" adalah suatu "wilayah" atau "lingkungan pemerintah". Dengan demikian pengertian secara istilah "otonomi daerah" adalah wewenang atau kekuasaan pada suatu wilayah atau daerah yang mengatur dan mengelola untuk kepentingan wilayah atau daerah masyarakat itu sendiri. Pengertian yang lebih luas lagi adalah wewenang atau kekuasaan pada suatu wilayah atau daerah yang 


\section{Kebijakan: Jurnal Ilmu Administrasi \\ Volume 11, Nomor 1, Januari 2020 \\ E-ISSN: 2656-2820 \\ P-ISSN 1829-5762}

mengatur dan mengelola untuk kepentingan wilayah atau daerah masyarakat itu sendiri mulai dari ekonomi, politik, dan pengaturan perimbangan keuangan termasuk pengaturan sosial, budaya, dan ideologi yang sesuai dengan tradisi adatistiadat daerah lingkungannya.Pelaksanaan otonomi daerah dipengaruhi oleh faktor-faktor yang meliputi kemampuan pelaksana, kemampuan dalam keuangan, ketersediaan alat dan bahan, serta kemampuan dalam berorganisasi. Otonomi daerah tidak mencakup bidang-bidang tertentu, seperti politik luar negeri, pertahanan keamanan, peradilan, moneter, fiskal, dan agama. Bidang-bidang tersebut tetap menjadi urusan pemerintah pusat. Pelaksanaan otonomi daerah berdasar pada prinsip demokrasi, keadilan, pemerataan, dan keanekaragaman.otonomi daerah tidak hanya pelaksanaan demokrasi pemerintahan dari, oleh, dan untuk rakyat.Rakyat tidak saja menentukan nasibnya melainkan juga memperbaiki nasibnya sendiri. Didalam UUD 1945 antara lain tersurat bahwa sistem pemerintahan Negara Kesatuan Republik Indonesia memberikan keleluasaan kepada daerah untuk menyelenggarakan otonomi daerah. Namun dalam praktiknya hal tersebut belum dilaksanakan secara proporsional sesuai dengan prinsip-prinsip demokrasi, keadilan dan pemerataan bahkan dalam kenyataannya, terlihat sangat kuatnya kekuasaan yang terpusat dan lemahnya kekuasaan daerah. Dalam perkembangannya, pemerintah pusat yang semula dalam posisi kuat, kenyataannya justru mengandung kelemahan. Hal ini antara lain disebabkan oleh berbagai permasalahan yang muncul.

\section{PEMBAHASAN}

Implikasi Otonomi Daerah di bidang Politik, Ekonomi, Sosial-Budaya dan Hukum Sebagian kalangan menilai bahwa kebijakan Otonomi Daerah di bawah UU 23 Tahun 2014 merupakan salah satu kebijakan Otonomi Daerah yang terbaik yang pernăh ada di Republik ini. Prinsip-prinsip dan dasar pemikiran yang digunakan dianggap sudah cukup memadai dengan kondisi dan kebutuhan masyarakat dan daerah. Kebijakan Otonomi Daerah yang pada hakekatnya adalah upaya pemberdayaan dan pendemokrasian kehidupan masyarakat diharapkan dapat memenuhi aspirasi berbagai pihak dalam konteks penyelenggaraan pemerintahan negara serta hubungan Pusat dan Daerah. Jika kita memperhatikan prinsip-prinsip pemberian dan penyelenggaraan Otonomi Daerah dapat diperkirakan ada implikasi ke depan dari Otonomi Daerah tersebut. Untuk mengetahui implikasi tersebut dapat dilakukan dengan menggunakan berbagai pendekatan. Salah satu pendekatan yang kita gunakan disini adalah aspek politik, ekonomi, sosial budaya, dan hukum.

\section{Implikasi pada politik}

Dari aspek politik, pemberian otonomi dan kewenangan kepada Daerah merupakan suatu wujud dari pengakuan dan kepercayaan Pusat kepada Daerah. Pengakuan Pusat terhadap eksistensi Daerah serta kepercayaan dengan memberikan kewenangan yang luas kepada Daerah akan menciptakan hubungan yang harmonis antara Pusat dan Daerah. Selanjutnya kondisi akan mendorong tumbuhnya dukungan Daerah terhadap Pusat dimana akhirnya akan dapat memperkuat persatuan dan kesatuan bangsa. Kebijakan Otonomi Daerah sebagai upaya pendidikan politik rakyat akan membawa dampak terhadap peningkatan kehidupan politik di Daerah. Hal ini sebagaimana tercantum dalam Pasal

\section{Implikasi pada ekonomi}

Dari aspek ekonomi, kebijakan Otonomi Daerah yang bertujuan untuk pemberdayaan kapasitas daerah akan memberikan kesempatan bagi Daerah untuk mengembangkan dan meningkatkan perekonomiannya. Peningkatan dan pertumbuhan perekonomian daerah akan membawa pengaruh 


\section{Kebijakan: Jurnal Ilmu Administrasi \\ Volume 11, Nomor 1, Januari 2020 \\ E-ISSN: 2656-2820 \\ P-ISSN 1829-5762}

yang signifikan terhadap peningkatan kesejahteraan rakyat di Daerah. Melalui kewenangan yang dimilikinya untuk mengatur dan mengurus kepentingan masyarakat, daerah akan berupaya untuk meningkatkan perekonomian sesuai dengan kondisi, kebutuhan dan kemampuan. Kewenangan daerah melalui Otonomi Daerah diharapkan dapat memberikan pelayanan maksimal kepada para pelaku ekonomi di daerah, baik lokal, nasional, regional maupun global. Bahkan kalau ditelaah lebih lanjut, sejak diberlakukannya otonomi daerah pada tanggal 1 Januari 2001 lalu, telah terjadi pelimpahan kewenangan yang semakin luas kepada pemerintahan daerah dalamrangka meningkatkan efektifitas dan efisiensi penyelenggaraan fungsi pemerintahdaerah. Pemberian otonomi daerah diharapkan dapat meningkatkan efisiensi,efektivitas, dan akuntabilitas sektor publik di Indonesia. Dengan otonomi, daerahdituntut untuk mencari alternatif sumber pembiayaan pembangunan tanpa mengurangi harapan masih adanya bantuan dan bagian (sharing) dari pemerintah pusat dan menggunakan dana publik sesuai dengan prioritas dan aspirasi masyarakat (Mardiasmo, 2002). Sebagai contoh dalam bidang pariwisata yang merupakan sektor riil pemasukan daerah. Seperti telah disinggung di muka, pelaksanaan otonomi yang diatur dalam UU 32 Tahun 2004, diyakini akan mendorong daerah untuk lebih bersikap mandiri karena memiliki kewenangan penuh untuk mengurus dan mengontrol daerahnya sendiri. Kemandirian tersebut, bisa menciptakan pertumbuhan ekonomi lebih baik, termasuk pengelolaan pariwisata daerah yang lebih profesional dan mengena. Dengan adanya otonomi, maka otomatis daerah akan lebih kreatif dalam menggali penerimaan daerahnya. Dampaknya terhadap pariwisata adalah adanya kesungguhan dalam mengkaii dan melestarikan objek-objek wisata, karena objek itu menjadi sumber pendapatan penting bagi daerah. Kemandirian ini juga diharapkan akan memacu kemandirian dalam bidang promosi wisata.

\section{Implikasi pada sosial budaya}

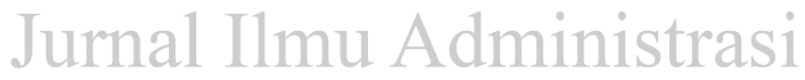

Dari aspek sosial budaya, kebijakan Otonomi Daerah merupakan pengakuan terhadap keanekaragaman Daerah, baik itu suku bangsa, agama, nilai-nilai sosial dan budaya serta potensi lainnya yang terkandung di daerah. Pengakuan Pusat terhadap keberagaman Daerah merupakan suatu nilai penting bagi eksistensi Daerah. Dengan pengakuan tersebut Daerah akan merasa setara dan sejajar dengan suku bangsa lainnya, hal ini akan sangat berpengaruh terhadap upaya mempersatukan bangsa dan negara. Pelestarian dan pengembangan nilai-nilai budaya lokal akan dapat ditingkatkan dimana pada akhirnya kekayaan budaya lokal akan memperkaya khasanah budaya nasional.

\section{Implikasi pada hukum}

Memperhatikan pemikiran dengan menggunakan pendekatan aspek politik, ekonomi, sosial budaya dan hukum, secara ideal kebijakan Otonomi Daerah merupakan kebijakan yang sangat tepat dalam penyelenggaraan pemerintahan di daerah. Hal ini berarti bahwa kebijakan Otonomi Daerah mempunyai prospek yang bagus di masa mendatang dalam menghadapi segala tantangan dalam penyelenggaraan kehidupan bermasyarakat, berbangsa dan bernegara. Namun demikian prospek yang bagus tersebut tidak akan dapat terlaksana jika berbagai kendala dan tantangan yang dihadapi tidak dapat diatasi dengan baik. Untuk dapat mewujudkan prospek Otonomi Daerah di masa mendatang tersebut diperlukan suatu kondisi yang kondusif diantaranya yaitu :

1. Adanya komitmen politik dari seluruh komponen bangsa terutama pemerintah dan lembaga perwakilan untuk mendukung dan memperjuangkan implementasi kebijakan Otonomi Daerah.

2. Adanya konsistensi kebijakan penyelenggara negara terhadap implementasi kebijakan Otonomi Daerah. 


\section{Kebijakan: Jurnal Ilmu Administrasi \\ Volume 11, Nomor 1, Januari 2020 \\ E-ISSN: 2656-2820 \\ P-ISSN 1829-5762}

3. Kepercayaan dan dukungan masyarakat serta pelaku ekonomi dalam pemerintah dalam mewujudkan cita-cita Otonomi Daerah.

Dengan kondisi tersebut bukan merupakan suatu hal yang mustahil Otonomi Daerah mempunyai prospek yang sangat cerah di masa mendatang. Kita berharap melalui dukungan dan kerjasama seluruh komponen bangsa kebijakan Otonomi Daerah dapat diimplementasikan dalam penyelenggaraan pemerintahan di daerah.

\section{Otonomi Daerah dan Pembagian Urusan Ke Depan}

Praktek pemerintahan daerah dengan ketentuan yang mengaturnya setidaknya telah mendorong dinamika lokal secara kompetitif. Sejumlah isu penting dalam praktek masih menimbulkan masalah. Konsekuensi logis ketentuan Pasal 18 Ayat (1) Undang-Undang Dasar Negara Republik Indonesia Tahun 1945 adalah adanya pembagian urusan pemerintah antara pemerintah pusat dan pemerintah daerah. Dengan kata lain, akan melahirkan suatu perimbangan kekuasaan antara pemerintah pusat dan pemerintah daerah. Urusan pemerintahan adalah fungsi-fungsi pemerintahan yang menjadi hak dan kewajiban setiap tingkatan dan/atau susunan pemerintahan untuk mengatur dan mengurus fungsifungsi tersebut yang menjadi kewenangannya dalam rangka melindungi, melayani, memberdayakan, dan menyejahterakan masyarakat. Berdasarkan UU Nomor 23 tahun 2014 klasifikasi urusan pemerintahan terdiri dari 3 urusan yakni urusan pemerintahan absolut, urusan pemerintahan konkuren, dan urusan pemerintahan umum. Urusan pemerintahan absolut adalah Urusan Pemerintahan yang sepenuhnya menjadi kewenangan Pemerintah Pusat. Urusan pemerintahan konkuren adalah Urusan Pemerintahan yang dibagi antara Pemerintah Pusat dan Daerah provinsi dan Daerah kabupaten/kota. Urusan pemerintahan umum adalah Urusan Pemerintahan yang menjadi kewenangan Presiden sebagai kepala

pemerintahan.

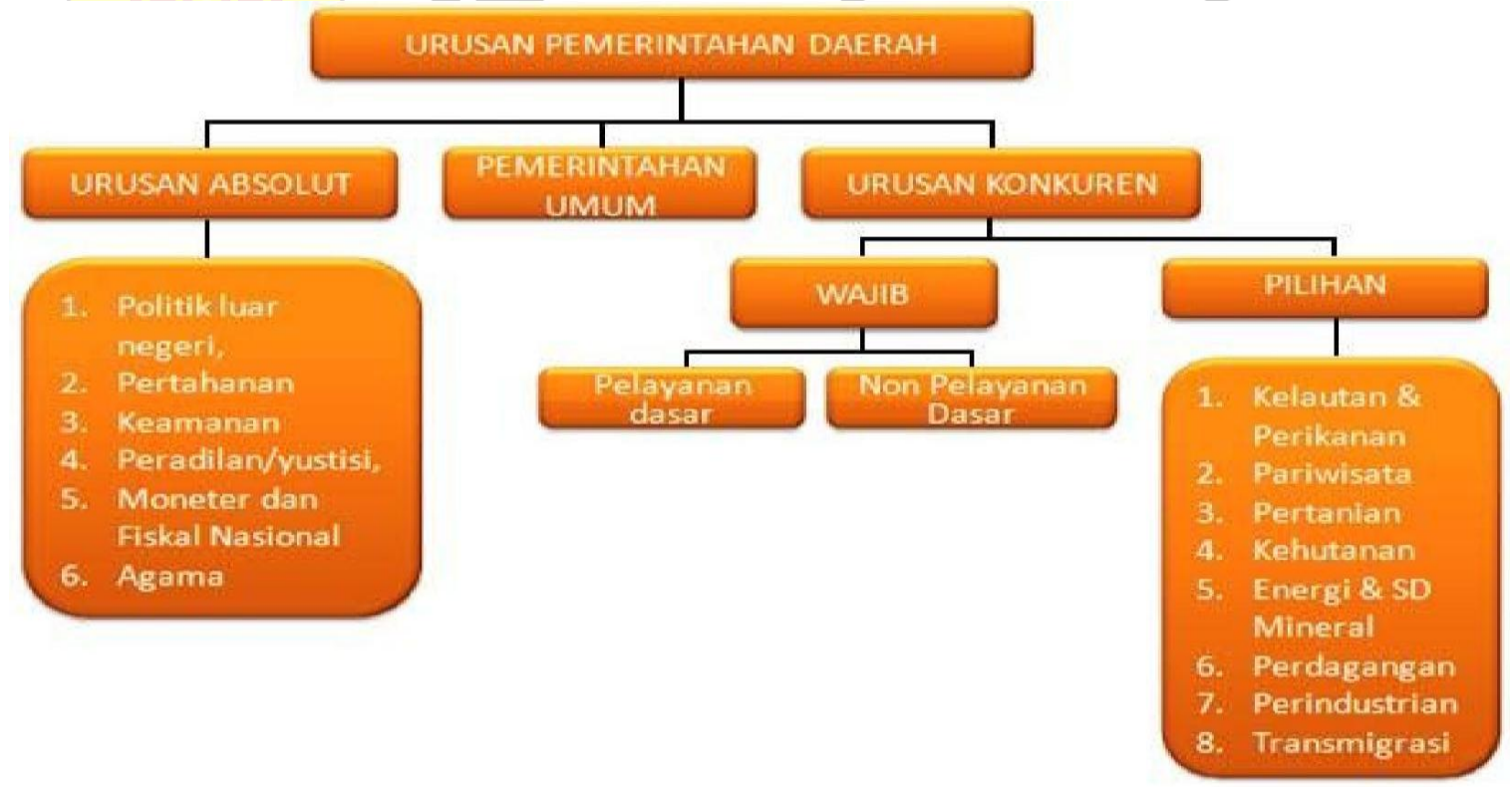

Urusan wajib dan urusan pilihan untuk pemerintahan daerah provinsi tentu saja berbeda dengan pemerintahan daerah kabupaten/kota. Hal ini dikarenakan ruang lingkup urusan pemerintahan daerah provinsi lebih luas dibandingkan dengan pemerintahan daerah kabupaten/kota. 
Kebijakan: Jurnal Ilmu Administrasi

Volume 11, Nomor 1, Januari 2020

E-ISSN: 2656-2820

P-ISSN 1829-5762

\begin{tabular}{|c|c|c|}
\hline No & $\begin{array}{l}\text { Urusan Wajib Pemerintahan Daerah } \\
\text { Provinsi }\end{array}$ & $\begin{array}{l}\text { Urusan Wajib Pemerintahan Daerah } \\
\text { Kabupaten/Kota }\end{array}$ \\
\hline 1 & $\begin{array}{lll}\text { Perencanaan } & \text { dan } & \text { pengendalian } \\
\text { pembangunan; } & & \end{array}$ & $\begin{array}{lll}\begin{array}{l}\text { Perencanaan } \\
\text { pembangunan; }\end{array} & \text { dan } & \text { pengendalian } \\
\end{array}$ \\
\hline 2 & $\begin{array}{l}\text { Perencanaan, pemanfaatan, dan } \\
\text { pengawasan tata ruang; }\end{array}$ & $\begin{array}{l}\text { Perencanaan, pemanfaatan, } \\
\text { pengawasan tata ruang; }\end{array}$ \\
\hline 3 & $\begin{array}{l}\text { Penyelenggaraan ketertiban umum dan } \\
\text { ketentraman masyarakat; }\end{array}$ & $\begin{array}{l}\text { Penyelenggaraan ketertiban umum dan } \\
\text { ketentraman }\end{array}$ \\
\hline 4 & Penyediaan sarana dan prasarana umum; & Penyediaan sarana dan prasarana umum; \\
\hline 5 & Penanganan bidang keseh & Penanganan bidang kesehatan; \\
\hline 6 & $\begin{array}{l}\text { Penyelenggaraan pendidikan dan alokasi } \\
\text { sumber daya manusia potensial; }\end{array}$ & Peny \\
\hline 7 & $\begin{array}{l}\text { Penanggulangan masalah sosial lintas } \\
\text { kabupaten/kota; }\end{array}$ & Pen \\
\hline 8 & $\begin{array}{l}\text { Pelayanan bidang ketenagakerjaan lintas } \\
\text { kabupaten/kota; }\end{array}$ & Pel \\
\hline 9 & $\begin{array}{l}\text { i pengembangan koperasi, usaha } \\
\text { an menengah termasuk lintas } \\
\text { en/kota; }\end{array}$ & $\begin{array}{l}\text { Fasilitasi pengembangan koperasi, usah } \\
\text { kecil dan menengah; }\end{array}$ \\
\hline 10 & Peng & Pengendali \\
\hline 11 & $\begin{array}{l}\text { Pelayanan pertanahan termasuk lintas } \\
\text { kabupaten/kota; }\end{array}$ & $\begin{array}{l}\text { Pelayanan pertanahan; } \\
\text { Ilnou Adnolnistrasi }\end{array}$ \\
\hline 12 & Pelayanan kependudukan, dan catatan Sipil & $\begin{array}{l}\text { Pelayanan kependudukan, dan catatan } \\
\text { sipil; }\end{array}$ \\
\hline 13 & $\begin{array}{l}\text { nan administrasi umum } \\
\text { ntahan; }\end{array}$ & $\begin{array}{l}\text { Pelayanan administrasi } \\
\text { pemerintahan; }\end{array}$ \\
\hline 14 & $\begin{array}{l}\text { an administrasi penanaman modal } \\
\text { k lintas kabupaten/kota; }\end{array}$ & $\begin{array}{l}\text { layanan administrasi penanaman } \\
\text { odal; }\end{array}$ \\
\hline 15 & $\begin{array}{l}\text { Penyelenggaraan pelayanan dasar lainnya } \\
\text { yang belum dapat dilaksanakan oleh } \\
\text { kabupaten/ kota; dan }\end{array}$ & $\begin{array}{l}\text { Penyelenggaraan pelayanan dasar } \\
\text { lainnya; dan }\end{array}$ \\
\hline 16 & $\begin{array}{l}\text { Urusan wajib lainnya yang diamanatkan } \\
\text { oleh peraturan perundang-undangan. }\end{array}$ & $\begin{array}{l}\text { Urusan wajib lainnya yang diamanatk } \\
\text { oleh peraturan perundang- undangan. }\end{array}$ \\
\hline
\end{tabular}

Dalam menyelenggarakan urusan pemerintahan yang menjadi kewenangan daerah, pemerintahan daerah menjalankan otonomi seluas-luasnya untuk mengatur dan mengurus sendiri urusan pemerintahan berdasarkan asas otonomi dan tugas pembantuan. Pelaksanaan urusan pemerintahan oleh daerah dapat diselenggarakan secara langsung oleh pemerintahan daerah itu sendiri dan dapat pula penugasan oleh pemerintah provinsi ke pemerintah kabupaten/kota dan desa atau penugasan dari pemerintah kabupaten/kota ke desa. Kepala daerah mempunyai kewenangan yang cukup besar untuk membangun daerah yang dipimpinnya. Apabila kewenangan tersebut dipergunakan sebagaimana mestinya, sudah pasti daerah yang dipimpinnya akan maju yang salah satu 


\section{Kebijakan: Jurnal Ilmu Administrasi \\ Volume 11, Nomor 1, Januari 2020 \\ E-ISSN: 2656-2820 \\ P-ISSN 1829-5762}

indikatornya adalah semakin meningkatnya kesejahteraan masyarakat. Akan tetapi, akhir-akhir ini kita sering melihat dan membaca berita mengenai oknum kepala daerah yang menjadi terpidana kasus korupsi, tindak pidana pencucian uang, dan tindak pidana lainnya yang merupakan bentuk penyalahgunaan jabatan dan kewenangan. Faktor penyebab munculnya korupsi antara lain : penegakan hukum tidak konsisten, mereka yang berkecukupan melakukan korupsi karena serakah, dan budaya permisif/serba membolehkan; tidakmau tahu : menganggap biasa bila ada korupsi, Apa dampak dari kasus tersebut bagi upaya perwujudan cita-cita dan tujuan negara sebagaimana tercantum dalam Pembukaan Undang- Undang Dasar Negara Republik Indonesia Tahun 1945?. Dampak korupsi terhadap perekonomian dan pembangunan nasional mengakibatkan pemborosan keuangan atau kekayaan negara. Korupsi dapat menghambat pertumbuhan dan pengembangan ekonomi. Bagaimana solusi untuk mencegah agar kasus korupsi yang melibatkan kepala daerah atau pejabat daerah lainnya tidak terus terulang? Menanamkan semangat nasional yang positif dengan mengutamakan pengabdian pada bangsa dan Negara, para pejabat dihimbau untuk mematuhi pola hidup sederhana dan memiliki tanggung jawab yang tinggi, sistem keuangan dikelola oleh para pejabat yang memiliki tanggung jawab tinggi dan dibarengi oleh system control yang efisien.

UU Nomor 23 Tahun 2014 tentang Pemerintahan Daerah dikeluarkan untuk menggantikan Undang-Undang Nomor 32 Tahun 2004 tentang Pemerintahan Daerah yang sudah tidak sesuai lagi dengan perkembangan keadaan, ketatanegaraan. dan tuntuuan pernyelenggaraan pemerintahan daerah. UU Nomor 23 Tahun 2014 tentang Pemerintahan Daerah telah disempurnakan sebanyak dua kali. Penyempurnaan yang pertama dengan dikeluarkannya Peraturan Pemerintah Pengganti UndangUndang Nomor 2 Tahun 2014 tentang Perubahan atas Undang-Undang Nomor 23 Tahun 2014 tentang Pemerintahan Daerah. Adapun perubahan kedua ialah dengan dikeluarkảnnya Undang-Undang Nomor 9 Tahun 2015 tentang Perubahan Kedua atas Undang-Undang Nomor 23 Tahun 2014 tentang Pemerintahan Daerah. Serangkaian UU Nomor 23 Tahun 2014 beserta perubahan-perubahannya tersebut menyebutkan adanya perubahan susunan dan kewenangan pemerintahan daerah. Seusunan pemerintahan daerah menurut UU ini meliputi pemerintahan daerah provinsi, pemerintahan daerah kebupaten, dan DPRD. Pemerintahan daerah terdiri atas kepala daerah dan DPRD dibantu oleh perangkat daerah. Pemerintahan daerah provinsi terdiri atas pemerintah daerah provinsi dan DPRD provinsi. Aadapun pemerintah daerah kabupaten/kota terdiri atas pemerintah daerah kabupaten/kota dan DPRD kabupaten/kota. Untuk urusan konkuren atau urusan pemerintahan yang dibagi antara Pemerintah Pusat dan Daerah provinsi dan Daerah kabupaten/kota dibagi menjadi urusan pemerintahan wajib dan urusan pemerintahan pilihan. Urusan Pemerintahan Wajib adalah Urusan Pemerintahan yang wajib diselenggarakan oleh semua Daerah. Sedangkan Urusan Pemerintahan Pilihan adalah Urusan Pemerintahan yang wajib diselenggarakan oleh Daerah sesuai dengan potensi yang dimiliki Daerah. Urusan Pemerintahan Wajib. Urusan pemerintah wajib yang diselenggaraan oleh pemerintah daerah terbagi menjadi Urusan Pemerintahan yang berkaitan dengan Pelayanan Dasar dan Urusan Pemerintahan yang tidak berkaitan dengan Pelayanan Dasar. 
Berikut pembagian urusan wajib.

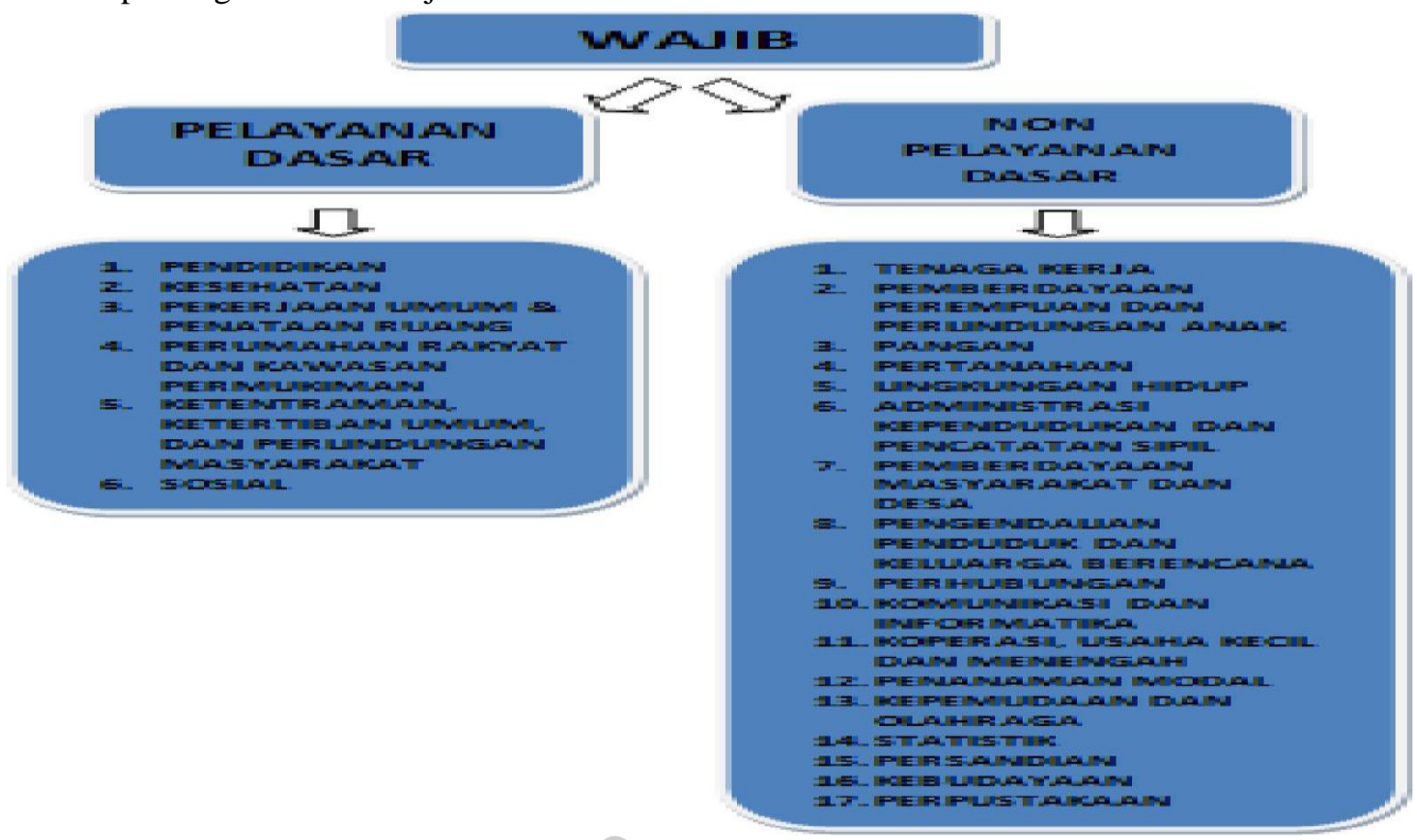

Pembagian urusan pemerintahan konkuren antara Pemerintah Pusat dan Daerah provinsi serta Daerah kabupaten/kota sebagaimana disebutkan diatas didasarkan pada prinsip akuntabilitas, efisiensi, dan eksternalitas, serta kepentingan strategis nasional. Berikut kriteria-kriteria urusan pemerintahan pusat, daerah provinsi dan daerah kabupaten/kota.

Kriteria Urusan Pemerintahan yang menjadi kewenangan Pemerintah Pusat adalah:

a. Urusan Pemerintahan yang lokasinya lintas Daerah provinsi atau lintas negara,

b. Urusan Pemerintahan yang penggunanya lintas Daerah provinsi atau lintas negara;

c. Urusan Pemerintahan yang manfaat atau dampak negatifnya lintas Daerah provinsi atau lintas negara;

d. Urusan Pemerintahan yang penggunaan sumber dayanya lebih efisien apabila dilakukan oleh Pemerintah Pusat; dan/atau

e. Urusan Pemerintahan yang peranannya strategis bagi kepentingan nasional.

Kriteria Urusan Pemerintahan yang menjadi kewenangan Pemerintah Daerah Provinsi adalah:

a. Urusan Pemerintahan yang lokasinya lintas Daerah kabupaten/kota;

b. Urusan Pemerintahan yang penggunanya lintas Daerah kabupaten/kota;

c. Urusan Pemerintahan yang manfaat atau dampak negatifnya lintas Daerah kabupaten/kota; dan/atau

d. Urusan Pemerintahan yang penggunaan sumber dayanya lebih efisien apabila dilakukan oleh Daerah Provinsi.

Kriteria Urusan Pemerintahan yang menjadi kewenangan Pemerintah Daerah Kabupaten/Kota adalah:

a. Urusan Pemerintahan yang lokasinya dalam Daerah kabupaten/kota;

b. Urusan Pemerintahan yang penggunanya dalam Daerah kabupaten/kota;

c. Urusan Pemerintahan yang manfaat atau dampak negatifnya hanya dalam Daerah kabupaten/kota; dan/atau 


\section{Kebijakan: Jurnal Ilmu Administrasi \\ Volume 11, Nomor 1, Januari 2020 \\ E-ISSN: 2656-2820 \\ P-ISSN 1829-5762}

d. Urusan Pemerintahan yang penggunaan sumber dayanya lebih efisien apabila dilakukan oleh Daerah kabupaten/kota.

Urusan Pemerintahan Pilihan Ketentuan mengenai pembagian urusan pemerintahan daerah dan pemerintah pusat dalam urusan pilihan adalah sebagai berikut.

1. Penyelenggaraan urusan pemerintahan bidang kehutanan, kelautan, serta energi dan sumber daya mineral dibagi antara Pemerintah Pusat dan Pemerintah Daerah.

2. Urusan Pemerintahan bidang kehutanan yang berkaitan dengan pengelolaan taman hutan raya kabupaten/kota menjadi kewenangan daerah kabupaten/kota.

3. Urusan pemerintahan bidang energi dan sumber daya mineral yang berkaitan dengan pengelolaan minyak dan gas bumi menjadi kewenangan Pemerintah Pusat.

4. Urusan Pemerintahan bidang energi dan sumber daya mineral yang berkaitan dengan pemanfaatan langsung panas bumi dalam daerah kabupaten/kota menjadi kewenangan daerah kabupaten/kota.

\section{Membangun Otonomi Daerah Ke Depan}

Sebagian kalangan menilai bahwa kebijakan Otonomi Daerah yang didasarkan pada UndangUndang Nomor 23 Tahun 2014 saat ini merupakan salah satu kebijakan Otonomi Daerah yang terbaik di Republik ini. Prinsip-prinsip dan dasar pemikiran yang digunakan dianggap sudah cukup memadai dengan kondisi dan kebutuhan masyarakat dan daerah. Kebijakan Otonomi Daerah yang pada hakekatnya adalah upaya pemberdayaan dan pendemokrasian kehidupan masyarakat diharapkan dapat memenuhi aspirasi berbagai pihak dalam konteks penyelenggaraan pemerintahan negara serta hubungan Pusat dan Daerah.

Jika kita memperhatikan prinsip-prinsip pemberian dan penyelenggaraan Otonomi Daerah dapat diperkirakan prospek ke depan dari Otonomi Daerah tersebut. Untuk mengetahui prospek tersebut dapat dilakukan dengan menggunakan berbagai pendekatan. Salah satu pendekatan yang kita gunakan disini adalah aspek ideologi, politik, sosial budaya, dan pertahanan keamanan. Dari aspek ideologi, sudah jelas dinyatakan bahwa Pancasila merupakan pandangan, falsafah hidup dan sekaligus dasar negara. Nilai-nilai Pancasila mengajarkan antara lain pengakuan Ketuhanan, semangat persatuan dan kesatuan nasional, pengakuan hak azasi manusia, demokrasi, dan keadilan dan kesejahteraan sosial bagi seluruh masyarakat. Jika kita memahami dan menghayati nilai-nilai tersebut maka dapat disimpulkan bahwa kebijakan Otonomi Daerah dapat diterima dalam penyelenggaraan kehidupan berbangsa dan bernegara. Melalui Otonomi Daerah nilai-nilai luhur Pancasila tersebut akan dapat diwujudkan dan dilestarikan dalam setiap aspek kehidupan bangsa Indonesia. Dari aspek politik, pemberian otonomi dan kewenangan kepada Daerah merupakan suatu wujud dari pengakuan dan kepercayaan Pusat kepada Daerah. Pengakuan Pusat terhadap eksistensi Daerah serta kepercayaan dengan memberikan kewenangan yang luas kepada Daerah akan menciptakan hubungan yang harmonis antara Pusat dan Daerah. Selanjutnya kondisi ini akan mendorong tumbuhnya dukungan Derah terhadap Pusat dimana akhirnya akan dapat memperkuat persatuan dan kesatuan bangsa. Kebijakan Otonomi Daerah sebagai upaya pendidikan politik rakyat akan membawa dampak terhadap peningkatan kehidupan politik di Daerah. Dari aspek ekonomi, kebijakan Otonomi Daerah yang bertujuan untuk pemberdayaan kapasitas daerah akan memberikan kesempatan bagi Daerah untuk mengembangkan dan meningkatkan perekonomiannya. Peningkatan dan pertumbuhan perekonomian daerah akan membawa pengaruh yang signifikan terhadap peningkatan kesejahteraan rakyat di Daerah. Melalui kewenangan yang dimilikinya untuk mengatur dan mengurus kepentingan masyarakat, daerah akan berupaya untuk 


\section{Kebijakan: Jurnal Ilmu Administrasi \\ Volume 11, Nomor 1, Januari 2020 \\ E-ISSN: 2656-2820 \\ P-ISSN 1829-5762}

meningkatkan perekonomian sesuai dengan kondisi, kebutuhan dan kemampuan. Kewenangan daerah melalui Otonomi Daerah diharapkan dapat memberikan pelayanan maksimal kepada para pelaku ekonomi di daerah, baik lokal, nasional, regional maupun global. Dari aspek sosial budaya, kebijakan Otonomi Daerah merupakan pengakuan terhadap keanekaragaman Daerah, baik itu suku bangsa, agama, nilai-nilai sosial dan budaya serta potensi lainnya yang terkandung di daerah. Pengakuan Pusat terhadap keberagaman Daerah merupakan suatu nilai penting bagi eksistensi Daerah. Dengan pengakuan tersebut Daerah akan merasa setara dan sejajar dengan suku bangsa lainnya, hal ini akan sangat berpengaruh terhadap upaya mempersatukan bangsa dan negara. Pelestarian dan pengembangan nilai-nilai budaya lokal akan dapat ditingkatkan dimana pada akhirnya kekayaan budaya lokal akan memperkaya khasanah budaya nasional.

Selanjutnya dari aspek pertahanan dan keamanan, kebijakan Otonomi Daerah memberikan kewenangan kepada masing-masing daerah untuk memantapkan kondisi Ketahanan daerah dalam kerangka Ketahanan Nasional. Pemberian kewenangan kepada Daerah akan menumbuhkan kepercayaan Daerah terhadap Pusat. Tumbuhnya hubungan dan kepercayaan Daerah terhadap Pusat akan dapat mengeliminir gerakan separatis yang ingin memisahkan diri dari Negara Kesatuan Republik Indonesia. Memperhatikan pemikiran dengan menggunakan pendekatan aspek ideologi, politik, sosial budaya dan pertahanan keamanan, secara ideal kebijakan Otonomi Daerah merupakan kebijakan yang sangat tepat dalam penyelenggaraan pemerintahan di daerah. Hal ini berarti bahwa kebijakan Otonomi Daerah mempunyai prospek yang bagus di masa mendatang dalam menghadapi segala tantangan dalam penyelenggaraan kehidupan bermasyarakat, berbangsa dan bernegara. Namun demikian prospek yang bagus tersebut tidak akan dapat terlaksana jika berbagai kendala dan tantangan yang dihadapi tidak dapat diatasi dengan baik. Untuk dapat mewujudkan prospek Otonomi Daerah di masa mendatang tersebut diperlukan suatu kondisi yang kondusif diantaranya yaitu: Adanya komitmen politik dari seluruh komponen bangsa terutama pemerintah dan lembaga perwakilan untuk mendukung dan memperjuangkan implementasi kebijakan Otonomi Daerah; Adanya konsistensi kebijakan penyelenggara negara terhadap implementasi kebijakan Otonomi Daerah; dan Kepercayaan dan dukungan masyarakat serta pelaku ekonomi dalam pemerintah dalam mewujudkan cita-cita Otonomi Daerah. Dengan kondisi tersebut bukan merupakan suatu hal yang mustahil Otonomi Daerah mempunyai prospek yang sangat cerah di masa mendatang. Kita berharap melalui dukungan dan kerjasama seluruh komponen bangsa kebijakan Otonomi Daerah dapat diimplementasikan dalam penyelenggaraan pemerintahan di daerah. Era otonomi daerah bukan merupakan ancaman bagi upaya pengembangan industri dan perdagangan, namun sebaliknya justru memberikan kesempatan dan dukungan bagi pengembangan perindustrian dan perdagangan. Dengan kewenangan yang dimiliki daerah untuk mengatur dan mengurus kepentingan masyarakatnya terbuka kesempatan untuk mengembangkan perindustrian dan perdagangan secara optimal di Daerah.

Dengan potensi sumber daya alam dan sumber daya manusia yang tersedia di Daerah diharapkan upaya pengembangan perindustrian dan perdagangan akan dapat diwujudkan. Potensi sumber daya alam yang tersedia di daerah menyediakan bahan baku yang cukup memadai bagi pengembangan industri. Sedangkan potensi SDM di daerah menyediakan tenaga kerja yang secara bertahap dapat ditingkatkan kualitasnya. Sebagaimana dikemukakan sebelumnya bahwa hambatan bagi pengembangan industri dan perdagangan di daerah adalah investasi modal dan penguasaan teknologi. Kondisi stabilitas politik dan keamanan yang kurang kondusif menyebabkan keraguan dan kecemasan investor asing untuk menanamkan modalnya di Indonesia . Demikian juga dengan keterbatasan penguasaan teknologi menyebabkan kualitas produksi belum memenuhi standar industri internasional. Menghadapi kondisi tersebut sebenarnya upaya pengembangan industri dan 


\section{Kebijakan: Jurnal Ilmu Administrasi \\ Volume 11, Nomor 1, Januari 2020 \\ E-ISSN: 2656-2820 \\ P-ISSN 1829-5762}

perdagangan masih mempunyai prospek yang cukup menjanjikan. Dampak krisis ekonomi yang terjadi belakangan, ternyata terhadap kalangan usaha kecil, menengah dan koperasi tidak begitu mengalami pengaruh yang berarti. Jadi dapat disimpulkan sementara bahwa kelompok usaha kecil, $\mathrm{m}$ eneng ah dan koperasi mempunyai pondasi yang cukup kuat untuk bertahan dalam goncangan krisis ekonomi yang hebat. Dengan demikian kelompok usaha kecil, m eneng ah dan koperasi mempunyai prospek yang cukup menjanjikan dalam pengembangan industri dan perdagangan.

Menghadapi persaingan global di era pasar bebas AFTA (ASEAN Free Trade Area), APEC ( Asia Pacific Economic Cooperation) maupun WTO (World Trade Organization), prospek pengembangan industri dan perdagangan akan lebih cerah jika diarahkan kepada kelompok usaha kecil, m eneng ah dan koperasi. Melalui pembinaan secara intensif dari Pemerintah serta pelibatan seluruh komponen perekonomian nasional, maka kelompok usaha kecil, menengah dan koperasi akan menjadi tulang punggung bagi perekonomian nasional. Di era otonomi daerah sejalan dengan kewenangan yang dimiliki Daerah pengembangan industri dan perdagangan akan lebih efektif jika diarahkan kepada kelompok usaha kecil menengah dan koperasi, karena pada umumnya setiap daerah memiliki kelompok usaha jenis tersebut. Dengan kewenangan yang dimiliki Daerah tersebut setiap daerah akan berupaya melakukan pembinaan terhadap kelompok usaha kecil menengah dan koperasi untuk mendukung pengembangan industri dan perdagangan sesuai dengan kondisi potensi dan kemampuan masing-masing daerah.

\section{KESIMPULAN}

Kebijakan Otonomi Daerah yang pada hakekatnya adalah upaya pemberdayaan dan pendemokrasian kehidupan masyarakat diharapkan dapat memenuhi aspirasi berbagai pihak dalam konteks penyelenggaraan pemerintahan negara serta hubungan Pusat dan Daerah. Berdasarkan UU Nomor 23 tahun 2014 klasifikasi urusan pemerintahan terdiri dari 3 urusan yakni urusan pemerintahan absolut, urusan pemerintahan konkuren, dan urusan pemerintahan umum. Urusan pemerintahan absolut adalah Urusan Pemerintahan yang sepenuhnya menjadi kewenangan Pemerintah Pusat. Urusan pemerintahan konkuren adalah Urusan Pemerintahan yang dibagi antara Pemerintah Pusat dan Daerah provinsi dan Daerah kabupaten/kota. Urusan pemerintahan umum adalah Urusan Pemerintahan yang menjadi kewenangan Presiden sebagai kepala pemerintahan. Dalam memperhatikan prinsip-prinsip pemberian dan penyelenggaraan Otonomi Daerah dapat diperkirakan prospek ke depan dari Otonomi Daerah tersebut. Untuk mengetahui prospek tersebut dapat dilakukan dengan menggunakan berbagai pendekatan. Salah satu pendekatan yang kita gunakan disini adalah aspek ideologi, politik, sosial budaya, dan pertahanan keamanan. Hal ini berarti bahwa kebijakan Otonomi Daerah mempunyai prospek yang bagus di masa mendatang dalam menghadapi segala tantangan dalam penyelenggaraan kehidupan bermasyarakat, berbangsa dan bernegara. Namun demikian prospek yang bagus tersebut tidak akan dapat terlaksana jika berbagai kendala dan tantangan yang dihadapi tidak dapat diatasi dengan baik. Untuk dapat mewujudkan prospek Otonomi Daerah di masa mendatang tersebut diperlukan suatu kondisi yang kondusif diantaranya yaitu: Adanya komitmen politik dari seluruh komponen bangsa terutama pemerintah dan lembaga perwakilan untuk mendukung dan memperjuangkan implementasi kebijakan Otonomi Daerah; Adanya konsistensi kebijakan penyelenggara negara terhadap implementasi kebijakan Otonomi Daerah; dan Kepercayaan dan dukungan masyarakat serta pelaku ekonomi dalam pemerintah dalam mewujudkan cita-cita Otonomi Daerah. Dengan kondisi tersebut bukan merupakan suatu hal yang mustahil Otonomi Daerah mempunyai prospek yang sangat cerah di masa mendatang. 


\section{Kebijakan: Jurnal Ilmu Administrasi \\ Volume 11, Nomor 1, Januari 2020 \\ E-ISSN: 2656-2820 \\ P-ISSN 1829-5762}

\section{DAFTAR PUSTAKA}

Abidin, Said, Zainal. 2004. Kebijakan Publik. Jakarta: Pancur Siwah.

Asshidiqie, Jumly. 2004. Etika Birokrasi Penegakan Hukum dan Good Governance. Jakarta: Lembaga Administrasi Negara.

Kartiwa, Asep.,2012., Mengelola Kewenangan Pemerintahan., Bandung : Lepsindo. Lembaga Administrasi Negara, 2009. Grand Design Reformasi Birokrasi. Jakarta: Lembaga Administrasi Negara.

MD, Mahfud. 2003. Krisis Masa Kini dan Orde Baru. Jakarta : Yayasan Obor Indonesia. Mustopadidjaja. AR., 2003., Manajemen Proses Kebijakan Publik ; Formulasi,

Implementasi dan Evaluasi Kinerja., Jakarta: LAN-RI dan Duta Foundation. Rahardiansyah, Trubus. 2012. Sistem Pemerintahan Indonesia. Jakarta : Universitas

Trisakti.

Rondinelli, Dennis A., 1981. Desentralization in Developing Countries: A. Review o Recent Experience. World Bank Staff Working Papers., Washington.

Rusli, Budiman. 2013. Kebijakan Publik, Membangun Pelayanan Publik Yang Responsif. Bandung : Hakim Publishing.

Saefullah, A. Djadja. 2007. Pemikiran Kontemporer Administrasi Publik, Perspektif Manajemen Sumber Daya Manusia Dalam Era Desentralisasi, Bandung: LP3AN Fisip Unpad.

Soetrisno, Loekman. 1995. Menuju Masyarakat Partisipatif. Yogyakarta : Kanisius.

Sumarto, Sj, Hetifah. 2003. Inovasi, Partisipasi dan Good Governance. Bandung : Yayasan Obor Indonesia.

Sutarto. 1993. Dasar Dasar Organisasi. Yogyakarta: Gadjah Mada University Press.

Syaukani, Afan Gaffar, Ryaas Rasyid, 2002., Otonomi Daerah dalam Negara Kesatuan., Yogyakarta: Pustaka Pelajar.

Tanuwidjaja, Sunny., 2009., Pola Partisipasi Politik dalam Era Reformasi., Jakarta : Analisis CSIS Vol. 38, No 3.

Tachjan. 2006. Implementasi Kebijakan Publik, Asosiasi Ilmu Politik Indonesia. Bandung: Puslit KP2W Lemlit Unpad.

Thoha, Miftah., 1985. Titik Berat Otonomi Daerah. Jakarta : Prisma.

Tjokroaminoto, Moeljarto. 2001. Pembangunan, Dilema dan Tantangan. Yogyakarta : Pustaka Pelajar.

Utomo, Tri Widodo., 2006., Pendelegasian Kewenangan Pemerintahan Daerah Kepada Kecamatan dan Kelurahan., Bandung : Humaniora.

Widodo, Joko. 2001. Good Governance. Surabaya : Insan Cendekia.

Peraturan Perundang-undangan: Undang - Undang Republik Indonesia Nomor 23 Tahun 2014 tentang Pemerintahan Daerah 